\author{
PrZEMYSEAW LitwiniUK ${ }^{1}$
}

\title{
Krajowy system ewidencji producentów rolnych po wyroku Trybunału Konstytucyjnego $z$ dnia 3 grudnia 2013 roku (sygn. akt P 40/12)
}

\section{Wprowadzenie}

$\mathrm{Z}$ dniem 1 stycznia 2015 roku wejdzie w życie ustawa z dnia 23 października 2014 roku o zmianie ustawy o krajowym systemie ewidencji producentów, ewidencji gospodarstw rolnych i ewidencji wniosków o przyznanie płatności. ${ }^{2}$ Nowelizacja ustawy jest konsekwencją wyroku Trybunału Konstytucyjnego z dnia 3 grudnia 2013 r., ${ }^{3}$ w którym, po zbadaniu kwestii przedstawionej w pytaniu prawnym Naczelnego Sądu Administracyjnego, dotyczącej regulacji art. 12 ust. 4 ustawy, Trybunał orzekł, iż przepis ten w zakresie, $w$ jakim nie przewiduje dopuszczalności nadania osobnych numerów identyfikacyjnych każdemu z małżonków w sytuacji, gdy istnieje między nimi rozdzielność majątkowa i posiadają odrębne gospodarstwa rolne, jest niezgodny $\mathrm{z}$ art. 32 ust. $1 \mathrm{w}$ związku z art. 18 Konstytucji.

Opracowanie niniejsze stanowi próbę oceny skuteczności wdrożenia przez ustawodawcę wytycznych poczynionych przez Trybunał w uzasadnieniu orzeczenia w świetle problemu zagrożenia tworzeniem przez małżonków, w nowych uwarunkowaniach prawnych, sztucznych warunków dla uzyskania pomocy publicznej.

Najistotniejszą zmianą wprowadzaną w drodze nowelizacji ustawy jest nadanie nowego brzmienia art. 12 ust. 4, zgodnie z którym dotychczas, w przypadku małżonków oraz współposiadaczy gospodarstwa rolnego, numer identyfikacyjny nadawany był tylko jednemu z nich (jednemu ze współmałżonków lub jednemu ze współposiadaczy) za zgodą drugiego. Ze zmienianego przepisu wynika zatem zasada, że małżonkowie (a także współposiadacze gospodarstwa rolnego) mogą otrzymać jeden tylko numer identyfikacyjny w stworzonej i prowadzonej na podstawie ustawy o KSEP ewidencji producentów. Co istotne, przepisy nie czynią wyjątku dla 
małżonków pozostających w ustroju rozdzielności majątkowej, posiadających gospodarstwa rolne w majątkach osobistych, czy też prowadzących oddzielne, niezależne od siebie gospodarstwa rolne, w ramach własnej działalności gospodarczej.

Przepisy nowelizujące formułują hipotezę oraz dyspozycję normy prawnej regulującej sytuację małżonków, co do zasady w identyczny sposób określając jednocześnie wyjątek od zasady ogólnej. Od dnia 1 stycznia 2015 roku bowiem, w przypadku małżonków oraz podmiotów będących współposiadaczami gospodarstwa rolnego, nadaje się jeden numer identyfikacyjny temu z małżonków lub współposiadaczy gospodarstwa, co do którego współmałżonek lub współposiadacz wyrazili pisemną zgodę. Jednocześnie jednak wprowadzono wyjątek, w ramach którego małżonek (współposiadacz) może uzyskać odrębny od współmałżonka (współposiadacza) numer identyfikacyjny, jeżeli prowadzi samodzielnie odrębne gospodarstwo rolne stanowiące zorganizowaną całość gospodarczą. W rezultacie, umożliwia to rolnikom - małżonkom, gospodarującym oddzielnie, w niezależnych od siebie gospodarstwach rolnych, ubieganie się o płatności z funduszy w ramach wspólnej polityki rolnej Unii Europejskiej na prowadzone przez nich osobno gospodarstwa rolne. A zatem limity powierzchni gruntów rolnych, do których przyznawana jest pomoc, będą obliczane odrębnie dla każdego z tych gospodarstw. Omawiana ustawa nowelizująca dokonała ponadto oparcia procedury w sprawie wpisu do ewidencji producentów na przepisach kodeksu postępowania administracyjnego, przy jednoczesnym przerzuceniu ciężaru dowodowego na stronę, która $\mathrm{z}$ dowodzonego faktu wywodzi skutki prawne. Warto podkreślić, iż w dotychczasowym brzmieniu ustawy, organ dokonujący wpisu do ewidencji producentów oraz nadający numer identyfikacyjny postępowania w zasadzie nie prowadził. Wpis i nadanie numeru był czynnością materialno-techniczną, co potwierdzane było zaświadczeniem wydawanym w trybie art. 12 ust. 1 ustawy. Natomiast odmowa nadania numeru następowała $\mathrm{w}$ trybie decyzji administracyjnej w przypadkach enumeratywnie wymienionych w art. 13 ust. 1 tej ustawy. Po zmianie ustawy, od dnia 1 stycznia 2015 roku postępowanie w sprawie wpisu do ewidencji prowadzone będzie $w$ trybie kodeksu postępowania administracyjnego, a producent ubiegający się o wpis korzysta $\mathrm{z}$ katalogu uprawnień przewidzianych $\mathrm{w}$ tej ustawie.

\section{Sytuacja małżonków w ustawie o KSEP}

Jak już wyżej wspomniano, nowelizacja ustawy o KSEP jest konsekwencją wyroku Trybunału Konstytucyjnego z dnia 3 grudnia 2013 r., w którym obalono domniemanie konstytucyjności niektórych norm tejże ustawy i zakreślono ustawodawcy 18-miesięczny termin na jej dostosowanie do wymagań stawianych przez ustawę zasadniczą. Ustawa z dnia 18 grudnia 2003 r. o krajowym systemie ewidencji producentów, ewidencji gospodarstw rolnych i ewidencji wniosków o przyznanie płatno- 
ści ${ }^{4}$ określa zasady tworzenia i prowadzenia, a także zakres i przeznaczenie krajowego systemu ewidencji producentów. Sam obowiązek ustanowienia systemu wynika wprost z art. 15 ust. 1 pkt f. rozporządzenia Rady (WE) nr 73/2009 z dnia 19 stycznia 2009 r. ustanawiającego wspólne zasady dla systemów wsparcia bezpośredniego dla rolników w ramach wspólnej polityki rolnej i ustanawiającego określone systemy wsparcia dla rolników, zmieniającego rozporządzenia (WE) 1290/2005, (WE) 247/2006, (WE) 378/2007 oraz uchylające rozporządzenie 1782/20035 (dalej: ,rozporządzenie 73/2009”), gdzie określono elementy systemu zintegrowanego, wskazując, iż system ten obejmuje między innymi jednolity system rejestrowania tożsamości każdego rolnika, który składa wniosek o pomoc. ${ }^{6} \mathrm{~W}$ przepisach krajowych ww. uregulowania znalazły odzwierciedlenie w ustawie o KSEP oraz w rozporządzeniu Ministra Rolnictwa i Rozwoju Wsi z dnia 19 sierpnia 2010 r. w sprawie szczegółowych wymagań, jakie powinny spełniać wniosek o wpis do ewidencji producentów oraz zaświadczenie o nadanym numerze identyfikacyjnym ${ }^{7}$ (dalej: „rozporządzenie w sprawie szczegółowych wymagań”). Stosownie do przepisów ustawy, system ma zadanie porządkowe, ale także kontrolne oraz referencyjne w stosunku do schematów pomocowych realizowanych przez Agencję Restrukturyzacji i Modernizacji Rolnictwa. Warunkiem koniecznym do ubiegania się o jakiekolwiek płatności realizowane przez agencję płatniczą jest uzyskanie wpisu do ewidencji producentów oraz uzyskanie numeru identyfikacyjnego.

Wpisu producenta do ewidencji producentów dokonuje się na jego wniosek (art. 11 ustawy o KSEP), przy czym ustawa nie uzależnia dokonania wpisu od spełniania dodatkowych warunków (np. wykazania posiadania gruntów rolnych), a wymienione enumeratywnie w ustawie przyczyny odmowy wpisu do ewidencji, zgodnie $\mathrm{z}$ art. 13, to przypadki, w których wnioskodawca nie jest producentem lub został mu już uprzednio nadany numer identyfikacyjny, przy czym producentem wedle ustawy może być nie tylko producent rolny (w tym rolnik, posiadacz gospodarstwa oraz posiadacz zwierzęcia), ale także organizacja producentów, przetwórca, podmiot prowadzący zakład utylizacyjny oraz potencjalny beneficjent. Warto podkreślić, iż ustawodawca nie przewiduje konieczności dokumentowania w jakikolwiek sposób faktu bycia producentem, choć posiadanie tego statusu stanowi warunek konieczny ubiegania się o wpis do ewidencji producentów (art. 13 ust. 1 ustawy o KSEP).

\footnotetext{
4 Tekst jednolity Dz.U. z 2012 r. poz. 86 ze zm., zwana dalej „ustawą o KSEP”.

$5 \quad$ Dz.Urz. UE L 30 z 31.01.2009 r., s. 16, ze zm.

6 Obowiązek ustanowienia jednolitego systemu rejestrowania tożsamości każdego beneficjenta wsparcia, który składa wniosek o przyznanie pomocy lub wniosek o płatność został powtórzony w art. 68 ust. 1 lit. f rozporządzenia Nr 1306/2013 z dnia 17 grudnia 2013 r. w sprawie finansowania wspólnej polityki rolnej, zarządzania nią i monitorowania jej oraz uchylające rozporządzenia Rady (EWG) nr 352/78, (WE) nr 165/94, (WE) nr 2799/98, (WE) nr 814/2000, (WE) nr 485/2008 w związku z art. 72 ust. 2, rozporządzenia Parlamentu Europejskiego i Rady (UE) nr 1307/2013 z dnia 17 grudnia 2013 r. ustanawiającym przepisy dotyczące płatności bezpośrednich dla rolników na podstawie systemów wsparcia w ramach wspólnej polityki rolnej oraz uchylającym rozporządzenie Rady (WE) nr 637/2008 i rozporządzenie Rady (WE) nr 73/2009.
} 
Ustawa o KSEP nie przewiduje też możliwości weryfikacji danych wskazywanych przez beneficjentów we wniosku. Źródłem danych wskazanych we wniosku o wpis do ewidencji producentów jest wyłącznie oświadczenie składającego wniosek. Tak szeroka definicja producenta, a także bardzo ograniczony dotychczas zakres postępowania administracyjnego umożliwia wpisanie się do ewidencji producentów w zasadzie każdego podmiotu (osoby fizycznej, osoby prawnej oraz jednostki organizacyjnej nieposiadającej osobowości prawnej) bez konieczności choćby uprawdopodobnienia faktu bycia producentem $w$ rozumieniu ustawy o KSEP. Jedyne ograniczenie zastosowano dla małżonków oraz podmiotów będących współposiadaczami gospodarstwa rolnego. Jak bowiem wskazano na początku niniejszego opracowania, zgodnie z dotychczasowym brzmieniem art. 12 ust. 4 ustawy o KSEP, w przypadku małżonków oraz podmiotów będących współposiadaczami gospodarstwa rolnego, nadaje się jeden numer identyfikacyjny; numer identyfikacyjny nadaje się temu z małżonków lub współposiadaczy, co do którego współmałżonek lub współposiadacz wyrazili pisemną zgodę.

Wskazać należy, iż art. 12 ust. 4 ustawy o KSEP od momentu wejścia ustawy w życie był przedmiotem wątpliwości interpretacyjnych sądów administracyjnych. Od początku jego obowiązywania pojawiały się wątpliwości co do jego stosowania w przypadku małżonków legitymujących się ustrojem rozdzielności majątkowej, czy też małżonków posiadających odrębne gospodarstwa rolne należące do ich majątków osobistych. Ostatecznie wykładnia tego przepisu ugruntowana została w orzecznictwie sądów administracyjnych w ten sposób, iż bez względu na ustrój majątkowy panujący pomiędzy małżonkami, czy też posiadania odrębnego od małżonka gospodarstwa rolnego, małżonkom nadaje się jeden numer identyfikacyjny. Przytoczyć należy chociażby wyrok Naczelnego Sądu Administracyjnego z dnia 3 września 2010 r., ${ }^{8}$ gdzie wskazano, iż: ,,przepis art. 12 ust. 4 ustawy z 18 grudnia 2003 r. o krajowym systemie ewidencji producentów (...) obliguje do nadania numeru identyfikacyjnego jednemu ze współmałżonków, niezależnie od ustroju majątkowego obowiązującego małżonków. Posiadanie nawet odrębnego gospodarstwa rolnego ze strony małżonka producenta rolnego, który wpisany jest do ewidencji producentów rolnych i legitymuje się numerem identyfikacyjnym, nie uprawnia współmałżonka posiadającego oddzielne gospodarstwo rolne, jako jego majątek odrębny, do dokonania samodzielnego wpisu do ewidencji producentów i nadania mu odrębnego od drugiego małżonka numeru identyfikacyjnego", czy też wyrok Naczelnego Sądu Administracyjnego z dnia 8 lipca 2009 r., ${ }^{9}$ w którym uznano, że „posiadanie odrębnego gospodarstwa rolnego ze strony współmałżonka producenta rolnego, który wpisany jest do ewidencji producentów i legitymuje się numerem identyfikacyjnym, nie uprawnia współmałżonka posiadającego oddzielne gospodar- 
stwo rolne, jako jego majątek osobisty, do ubiegania się o wpis do ewidencji producentów i nadania numeru identyfikacyjnego". Identyczne stanowisko zajął NSA w wyrokach II GSK 23/09 oraz II GSK 94/10.

Idei takiej konstrukcji przepisu art. 12 ust. 4 ustawy o KSEP dopatrywać należy się w konieczności zapobieżenia sytuacji tworzenia przez beneficjentów (małżonków, współposiadaczy) sztucznych warunków do otrzymania wyższej pomocy. Chodzi tu w szczególności o płatności, których dotyczy limitacja uprawnionej powierzchni, a wysokość płatności naliczana jest degresywnie. Taka sytuacja występuje w przypadku płatności objętych Programem Rozwoju Obszarów Wiejskich zarówno dla lat 2004-2006, jak i 2007-2013, w tym pomocy finansowej na wspieranie działalności rolniczej na obszarach o niekorzystnych warunkach gospodarowania (ONW), Płatności rolnośrodowiskowej, działania „Modernizacja gospodarstw rolnych” oraz „Tworzenie i rozwój mikroprzedsiębiorstw”.

Wydaje się zatem, iż celem ustawodawcy było zapobieżenie sytuacji oddzielnego rejestrowania się małżonków w ewidencji producentów, a tym samym uniemożliwienie niezależnego od siebie ubiegania się o przyznanie płatności do sztucznie podzielonego gospodarstwa. Powyższe wydaje się być uzasadnione. Po pierwsze - celem, o którym mowa powyżej, ale także poprzez fakt, iż podstawą ustroju rolnego w Polsce są gospodarstwa rodzinne (art. 23 Konstytucji RP). Gospodarstwo rodzinne $\mathrm{w}$ zamyśle ustawodawcy winno stanowić jeden organizm ekonomiczny, utrzymywany pracą członków rodziny zamieszkującej w tym gospodarstwie. Szczegółowe kwestie własnościowe w ramach konstrukcji gospodarstwa rodzinnego odgrywają wtórną rolę. Także definicja gospodarstwa rolnego zawarta w art. 2 lit. b rozporządzenia 73/2009, określająca je jako wszystkie jednostki produkcyjne zarządzane przez rolnika znajdujące się na terytorium tego samego państwa członkowskiego ${ }^{10}$ - uzasadniała w pewnym stopniu nadanie takiego kształtu art. 12 ust. 4 ustawy o KSEP. W przeważającej bowiem większości, gospodarstwa rolne w Polsce prowadzone są wspólnie przez małżonków. Praktyka pokazuje, że nawet w sytuacjach, gdy małżonkowie posiadają gospodarstwa rolne przynależne do ich majątków osobistych, to jednak faktycznie prowadzą je wspólnie, tj. z wykorzystaniem tych samych maszyn rolniczych, środków produkcji, wspólnie sprzedają płody rolne, razem prowadzą gospodarkę finansową. Zatem formalnie dwa gospodarstwa rolne w rozumieniu przepisów Kodeksu cywilnego, a także stosownie do przepisów Kodeksu rodzinnego i opiekuńczego w zakresie ustroju majątkowego małżonków, pozostają jednym gospodarstwem z punktu widzenia definicji zawartej w rozporządzeniu 73/2009, do której także odsyła ustawa o KSEP.

Zgodnie z art. 4 lit. b rozporządzenia 1307/2013 uchylającego m.in. rozporządzenie 73/2009, gospodarstwo rolne to wszystkie jednostki wykorzystywane do działalności rolniczej i zarządzane przez rolnika, znajdujące się na terytorium tego samego państwa członkowskiego. 


\section{Wyrok Trybunału Konstytucyjnego}

W wyniku pytania prawnego skierowanego przez Naczelny Sąd Administracyjny, Trybunał Konstytucyjny orzekł, że art. 12 ust. 4 ustawy o KSEP w zakresie, w jakim uniemożliwia nadanie obu małżonkom numerów identyfikacyjnych, w sytuacji istnienia ustroju rozdzielności majątkowej małżeńskiej i prowadzenia przez każdego z małżonków odrębnych gospodarstw rolnych jest niezgodny z art. 32 Konstytucji RP w związku z art. 18 ustawy zasadniczej, bowiem w sposób nieuzasadniony i nieuprawniony różnicuje sytuację prawną rolnika w zależności od stanu cywilnego. W uzasadnieniu wyroku Trybunał Konstytucyjny wskazał, że problem konstytucyjny w niniejszej sprawie jest związany z nieuwzględnieniem w kwestionowanym przepisie okoliczności, iż jest możliwa i w praktyce występuje sytuacja, gdy każdy z małżonków prowadzi odrębne gospodarstwo rolne. Tymczasem kwestionowana regulacja umożliwia wpisanie do rejestru producentów i nadanie numeru identyfikacyjnego tylko jednemu małżonkowi, zakładając, że małżonkowie zawsze gospodarują wspólnie. Trybunał zwrócił uwagę, że posiadanie i prowadzenie przez małżonków odrębnych gospodarstw rolnych może mieć miejsce zarówno w przypadku rozdzielności majątkowej, jak i wspólności majątkowej. Jak pokazała rozpatrywana przez NSA sprawa, w związku z którą ten sąd skierował pytanie prawne do Trybunału, istnieje jednak taka możliwość, że małżonkowie, choć żyjący wspólnie, nie prowadzą razem gospodarstwa. Przeciwnie, prowadzą dwa, niezależne od siebie, wyodrębnione ekonomicznie i organizacyjnie oraz terytorialnie gospodarstwa, często ukierunkowane na różne rodzaje produkcji, prowadzące całkowicie niezależnie księgowość, posiadające REGON i wszelkie inne atrybuty pozwalające je uznać za odrębne gospodarstwa. W takiej sytuacji, stosowanie zaskarżonego przepisu mogło spowodować wyłączenie jednego z nich z systemu płatności. Jak wskazał skład orzekający, ,w sytuacji, gdy w świetle art. 15 ust. 1 lit. f rozporządzenia nr 73/2009, art. 5 rozporządzenia nr 1122/2009 oraz art. 4 rozporządzenia nr 65/2011, oboje małżonkowie spełniają kryteria uznania ich za rolników prowadzących działalność rolniczą w posiadanych przez nich gospodarstwach rolnych, odmowa wpisu do ewidencji jednego z małżonków wykracza poza cel, jaki mają realizować przepisy ustawy o systemie ewidencji". Zaskarżona regulacja nie spełnia wymagań proporcjonalności, skoro efektem obowiązywania kwestionowanego przepisu jest wyłączenie pewnej grupy podmiotów z systemów wsparcia przewidzianych dla rolników. Trybunał nie dostrzegł również wartości konstytucyjnej, której miałoby służyć zróżnicowanie wprowadzone przez kwestionowany przepis, a nawet przeciwnie - stwierdził, że jest on niezgodny z wartościami wyrażonymi w art. 18 Konstytucji RP. Biorąc pod uwagę powyższe okoliczności, Trybunał ocenił, że zróżnicowanie podmiotów podobnych w wyniku obowiązywania kwestionowanego przepisu nie jest usprawiedliwione. Oznacza to, że art. 12 ust. 4 ustawy o systemie ewidencji w zakresie, w jakim nie przewiduje dopuszczalności nadania osobnych numerów 
identyfikacyjnych każdemu z małżonków, w sytuacji gdy istnieje między nimi rozdzielność majątkowa i posiadają odrębne gospodarstwa rolne, uznany został za niezgodny z art. 32 ust. $1 \mathrm{w}$ związku z art. 18 Konstytucji.

Oceniając powyższe, w zasadzie zgodzić należy się z oceną dokonaną przez Trybunał. Zgodnie z utrwalonym orzecznictwem zasada równości (art. 32 ust. 1 Konstytucji RP) polega na tym, iż wszystkie podmioty prawa (adresaci norm prawnych) charakteryzujące się daną cechą istotną (relewantną) w równym stopniu mają być traktowane równo, tzn. według jednakowej miary, bez zróżnicowań zarówno dyskryminujących, jak i faworyzujących. Jeżeli kontrolowana norma traktuje odmiennie adresatów, którzy charakteryzują się wspólną cechą istotną mamy do czynienia z odstępstwem od zasady równości. Należy jednak podkreślić, że nie zawsze jest to jednak równoznaczne $\mathrm{z}$ istnieniem dyskryminacji lub uprzywilejowania. Konieczna jest jeszcze ocena kryterium, na podstawie którego dokonano owego zróżnicowania. ${ }^{11}$ Zasada równości oznacza przede wszystkim zakaz nieuzasadnionego różnicowania sytuacji prawnej podmiotów podobnych, ${ }^{12}$ ale zakłada jednocześnie różne traktowanie podmiotów różnych, tj. podmiotów, które nie posiadają wspólnej cechy istotnej. ${ }^{13}$ Równość wobec prawa to także zasadność wyboru takiego, a nie innego kryterium zróżnicowania. ${ }^{14}$ Najważniejszego znaczenia nabiera zatem ustalenie „cechy istotnej”, przesądzającej o uznaniu porównywanych podmiotów za podobne lub odmienne. Należy jednak pamiętać, że ustawodawcy przysługuje przy tym pewna swoboda określenia cechy relewantnej, według której dokonywane jest zróżnicowanie sytuacji prawnej poszczególnych adresatów. Rozumienie zasady równości musi uwzględniać ponadto dziedzinę stosunków, jakich dotyczy regulacja prawna wprowadzająca określone zróżnicowanie. Im słabsza jest bowiem ranga czy ochrona wolności, prawa lub innej konstytucyjnej wartości, ,towarzyszącej” dokonywanemu zróżnicowaniu, tym większa jest swoboda ustawodawcy przyjmowania cech relewantnych, tzn. takich, które wprowadzają to zróżnicowanie; tym większa winna być też gotowość Trybunału Konstytucyjnego do akceptowania odmiennego traktowania sytuacji w zasadzie podobnych.

W przypadku analizowanych przepisów ustawy o KSEP doszło zatem do zróżnicowania sytuacji podmiotów będących w podobnej sytuacji, tj. osób żyjących wspólnie bez zawarcia związku małżeńskiego z osobami żyjącymi wspólnie w związku małżeńskim, pozostawiając tym pierwszym prawo do posiadania własnych gospodarstw i w tym zakresie swobodnej możliwości korzystania z funduszy unijnych, przy domniemaniu co do małżonków, że nie mogą oni gospodarować od-

11 Por. wyroki TK z: dnia 24 lutego 1999 r., sygn. SK 4/98, OTK ZU nr 2/1999, poz. 24; dnia 9 maja 2005 r., sygn. SK 14/04, OTK ZU nr 5/A/2005, poz. 47; dnia 27 marca 2007 r., sygn. SK 9/05, OTK ZU nr 3/A/2007, poz. 31. Por. wyrok TK z dnia 13 kwietnia 1999 r., sygn. K 36/98, OTK ZU nr 3/1999, poz. 40.

13 Por. wyrok TK z dnia 27 stycznia 2010 r., sygn. SK 41/07, OTK ZU nr 1/A/2010, poz. 5 i powołane tam orzecznictwo.

14 Por. orzeczenie TK z dnia 9 marca 1988 r., sygn. U 7/87, OTK w 1988 r., poz. 1. 
dzielnie, jako niezależni gospodarze - przedsiębiorcy i w tym zakresie w pełni korzystać z funduszy unijnych. Dlatego orzeczenie Trybunału uznać należy za trafne, pamiętając przede wszystkim o tym, iż domniemanie wspólnego gospodarowania przez małżonków może być obalone poprzez wykazanie odrębnego gospodarowania małżonków w niezależnych od siebie gospodarstwach.

Podkreślenia wymaga, iż Trybunał Konstytucyjny na podstawie art. 190 ust. 3 Konstytucji RP odroczył o 18 miesięcy utratę mocy obowiązującej ww. przepisu. Uzasadniając to rozstrzygnięcie wskazal, iż ,wyeliminowanie z porządku prawnego art. 12 ust. 4 ustawy o systemie ewidencji w zakresie w jakim nie przewiduje nadania osobnych numerów identyfikacyjnych każdemu z małżonków, w sytuacji gdy istnieje między nimi rozdzielność majątkowa i posiadają odrębne gospodarstwa rolne, nie jest wystarczające dla przywrócenia stanu zgodności z Konstytucją. Niezbędna jest interwencja ustawodawcy (...). Oprócz nadania nowego brzmienia art. 12 ust. 4 ustawy o systemie ewidencji, z uwzględnieniem niniejszego wyroku, niezbędne jest zamieszczenie w ustawie przepisów, które będą przeciwdziałać nadużyciom, polegającym na pozornych lub sztucznych podziałach gospodarstw rolnych dla uzyskania nienależnych lub wyższych płatności, a w szczególności przyznanie kompetencji kontrolnych właściwemu organowi w trakcie postępowania o wpis do ewidencji i nadanie numeru ewidencyjnego, a także później, już po dokonaniu wpisu do ewidencji. Na wnioskodawcach - małżonkach, występujących z wnioskiem o osobne wpisy do ewidencji spoczywa ciężar wykazania, że posiadają i prowadzą odrębne gospodarstwa rolne. Konieczne jest jednak ustawowe określenie przesłanek ustalenia, że taka sytuacja rzeczywiście występuje". Trybunał zwrócił także uwagę, iż „okoliczność, że między małżonkami została ustanowiona rozłączność majątkowa, nie ma znaczenia rozstrzygającego, jakkolwiek jest to przesłanka istotna dla przyjęcia odrębności gospodarstw. Istotne są także okoliczności ustanowienia rozłączności, np. czy nastąpiło to przed, czy po wejściu w życie przepisów dotyczących dokonywania płatności. Dalszymi przesłankami mogą być usytuowanie gospodarstw w przestrzeni albo ich wyposażenie w infrastrukturę. Szczególną uwagę należy poświęcić przypadkom, w których wskutek traktowania gospodarstw rolnych jako odrębnych przysługujące płatności są wyższe niż w razie traktowania gospodarstwa obojga małżonków jako jednej całości”.

Takie uzasadnienie wyroku świadczyć może o dostrzeżeniu przez Trybunał trudnej materii z zakresu europejskiego prawa rolnego, jaką jest kwestia podejmowania prób tworzenia sztucznych warunków do uzyskania płatności. Sytuacja niezdefiniowana dotąd w przepisach prawa krajowego i europejskiego, scharakteryzowana została w orzecznictwie Europejskiego Trybunału Sprawiedliwości, który podjął się próby określenia cech takiego zjawiska, ale na tle różnych rozwiązań stosowanych $\mathrm{w}$ poszczególnych rodzajach płatności. Za obowiązek prawodawców państw członkowskich uznać należy wprowadzanie regulacji przeciwdziałają- 
cych tworzeniu sztucznych warunków dla uzyskania płatności z budżetu Unii Europejskiej. W przypadku uchwalenia dotychczas obowiązujących przepisów ustawy o KSEP, próbę uwzględnienia tej dyrektywy uznać należy za dyskryminującą i jednocześnie nieskuteczną. Ustawodawca stanął w konieczności wprowadzenia nowych rozwiązań w tym zakresie.

\section{Nowelizacja ustawy o KSEP - najważniejsze problemy}

Jak wskazano na wstępie niniejszego opracowania, z dniem 1 stycznia 2015 r. wchodzi w życie ustawa nowelizująca ustawę o KSEP w zakresie wynikającym z omawianego wyroku Trybunału Konstytucyjnego. Ustawodawca postanowił pozostawić jako zasadę praktykę wpisywania do ewidencji jednego z małżonków za zgodą drugiego, uwzględniając jednocześnie fakt, iż w sytuacji gdy małżonkowie prowadzą dwa niezależne od siebie gospodarstwa mogą uzyskać dwa niezależne od siebie wpisy do ewidencji. Powyższe wymagać będzie jednak właściwego udokumentowania i poddane będzie weryfikacji organu dokonującego wpisów z uwzględnieniem konieczności ustalenia odrębności gospodarstw i przeciwdziałania tworzeniu sztucznych warunków.

Inicjatywę ustawodawczą po wyroku Trybunału Konstytucyjnego podjął Senat RP, przedstawiając w czerwcu 2014 roku projekt ustawy. Uchwałą z dnia 6 czerwca 2014 r. w sprawie wniesienia do Sejmu projektu ustawy o krajowym systemie ewidencji producentów, ewidencji gospodarstw rolnych oraz ewidencji wniosków o przyznanie płatności, Senat przedstawił dość oszczędny projekt, w którym przewidziano zmiany w zakresie brzmienia art. 11 , art. 12 ust. 4 i 6 oraz art. 17. Z treści rzeczonego projektu wynikało, iż zmiany, które w opinii Senatu RP, wypełniają dyspozycję wyroku Trybunału polegać miałyby na:

- wprowadzeniu obowiązku przedstawiania na żądanie organu (kierownika biura powiatowego Agencji) dokumentów potwierdzających prowadzenie działalności rolniczej $\mathrm{w}$ oddzielnym gospodarstwie rolnym (poprzez dodanie do art. 11 ust. 1a) oraz

- zmianie dotychczasowego brzmienia art. 12 ust. 4 w ten sposób, iż wymóg posiadania jednego numeru identyfikacyjnego dotyczyłby wyłącznie współposiadaczy gospodarstwa rolnego, co wyłączyłoby z tego przepisu małżonków prowadzących odrębne gospodarstwa rolne,

- zmianie brzmienia art. 17, ustalającego delegację do wydania rozporządzenia przez Ministra Rolnictwa i Rozwoju Wsi do określenia dokumentów potwierdzających prowadzenie działalności rolniczej w oddzielnym gospodarstwie rolnym, uwzględniając dokumenty uprawdopodabniające posiadanie środków produkcji rolnej, w tym gruntów rolnych oraz dokumenty wskazujące na samodzielne ponoszenie przez wnioskodawcę wydatków. 
W uzasadnieniu do przedłożonego projektu wskazano, iż kwestie dotyczące uwzględnienia w ustawie sugerowanych przez Trybunał rozwiązań kontrolnych, które w sposób szczególny pozwalałaby sprawdzać, czy małżonkowie nie dokonują pewnych czynności mających na celu sztuczne podziały gospodarstw w celu uzyskania wyższych płatności, nie są konieczne. Po pierwsze bowiem, w opinii Senatu istnieją już rozwiązania mające na celu przeciwdziałanie takim praktykom, niezależnie od stanu cywilnego wnioskodawców. Po drugie zaś, takie rozwiązania, jeśli miałyby istnieć nie powinny zostać ograniczone wyłącznie do małżonków. W opinii Senatu: „rozbudowane badanie intencji podziału gospodarstw rolnych, tego czy podzielone gospodarstwa spełniają rzeczywiście samodzielne funkcje, czy podzielone grunty są zaopatrzone w osobne urządzenia i maszyny, choć możliwe - mogłoby okazać się dla Agencji bardziej kosztochłonne niż ewentualne korzyści finansowe Unii polegające na odebraniu (nieprzyznaniu) należnych świadczeń (...)”. W uzasadnieniu senackiego projektu ustawy podkreślono ponadto, iż dodatkowy mechanizm kontroli (art. 11 ust. 1a) wprowadzono na wniosek Ministra Rolnictwa i Rozwoju Wsi. A zatem pierwotny (przed uwagami Ministra) projekt ustawy przedłożony przez Komisję Ustawodawczą Senatu, zakładał jedynie dodanie przepisu, na podstawie którego tylko małżonkowie będący współposiadaczami gospodarstwa rolnego wpisywani byliby do ewidencji „,łącznie”, tj. tylko jeden z nich za zgodą drugiego (jak dotychczas). W przypadku przeciwnym małżonkowie, którzy nie współposiadają gospodarstwa, mogliby się ubiegać o odrębny wpis do ewidencji producentów.

Wydaje się, że takie podejście nie uwzględniało w żaden sposób wskazanych w uzasadnieniu wyroku Trybunału Konstytucyjnego kwestii, określonych tam jako kluczowe, aby ,przeciwdziałać nadużyciom, polegającym na pozornych lub sztucznych podziałach gospodarstw rolnych dla uzyskania nienależnych lub wyższych płatności". Uchwalenie projektu ustawy w wersji zaproponowanej przez Senat, tj. umożliwiającej nadanie odrębnego numeru identyfikacyjnego małżonkom, bez możliwości weryfikacji ich oświadczenia co do posiadania odrębnych gospodarstw, w znacznym stopniu uniemożliwiłoby przeciwdziałanie sztucznym podziałom gospodarstw, a wręcz stanowiłoby szerokie pole do nadużyć w tym zakresie. Wydaje się bowiem, iż zaproponowane przepisy, wykluczające jakąkolwiek możliwość weryfikacji składanych oświadczeń, otwierające możliwość wpisywania się do ewidencji producentów przez każdego oraz opieranie się przez organ tylko na złożonym wniosku, stanowić mogłyby swoistą zachętę do wykorzystywania możliwości uzyskania wyższych płatności.

Dużym niedopowiedzeniem wydaje się być również użyta w uzasadnieniu do przedłożonego projektu ustawy myśl, iż badanie intencji podziału gospodarstw oraz tego, czy dwa gospodarstwa rzeczywiście spełniają samodzielne funkcje ,mogłoby się okazać dla Agencji bardziej kosztochłonne niż ewentualne korzyści finansowe Unii polegające na odebraniu (nieprzyznaniu) należnych świadczeń (...)”. 
Podkreślić bowiem należy, iż zgodnie z art. 31 ust. 1 rozporządzenia Rady (WE) $\mathrm{Nr}$ 1290/2005 oraz art. 7 ust. 4 poprzedzającego je rozporządzenia Rady (WE) Nr 1258/1999, które stanowią, iż Komisja decyduje o kwotach podlegających wyłączeniu z finansowania Wspólnoty, jeżeli stwierdzi, że wydatki finansowane z Europejskiego Funduszu Orientacji i Gwarancji Rolnej (EFOGR), Europejskiego Funduszu Rolniczego Gwarancji (EFRG), Europejskiego Funduszu Rolnego na rzecz Rozwoju Obszarów Wiejskich (EFROW) nie zostały dokonane zgodnie z zasadami wspólnotowymi. Stosownie do powyższego, stwierdzenie przez Komisję, iż pomoc jest przyznawana w sposób sprzeczny z zasadami prawa unijnego może skutkować negatywnymi konsekwencjami finansowymi dla państwa członkowskiego, bowiem wyłączenie z finansowania przez Unię części poniesionych już przez dane państwo wydatków na wypłatę pomocy oznacza de facto obciążenie tymi kosztami budżetu krajowego.

Wobec powyższego oraz na wniosek Ministra Rolnictwa i Rozwoju Wsi brzmienie projektu ustawy uzupełnione zostało o przepis art. 11 poprzez dodanie ust. 1a wprowadzającego obowiązek przedstawiania na żądanie kierownika biura powiatowego Agencji dokumentów potwierdzających prowadzenie działalności rolniczej w oddzielnym gospodarstwie rolnym. Jednak można ocenić, iż zaproponowane przez Senat brzmienie art. 11 ust. 1a nie mogło zasługiwać na aprobatę, albowiem nie wypełniało wymogów postawionych przez Trybunał, a ponadto nie korespondowało w żaden sposób z pozostałymi przepisami ustawy. Po pierwsze bowiem użyte przez Senat sformułowanie „oddzielne gospodarstwo rolne” z punktu widzenia Krajowego Systemu Ewidencji Producentów jest nieprecyzyjne i mogłoby okazać się niewystarczające. Działalność rolnicza zawsze jest prowadzona w oddzielnym gospodarstwie rolnym, oddzielnym od innych gospodarstw. Zaproponowany przepis nie precyzował, na czym ma polegać owa oddzielność oraz nie wskazywał, od czyjego gospodarstwa ma ono być oddzielne (być może umieszczenie tego przepisu w art. 12 stanowiącym o zasadach wpisu do ewidencji małżonków dałoby wyraz intencji projektodawcy, jednak umieszczenie tego przepisu w art. 11 czyniło zamysł autora zupełnie niejasnym). Wydaje się, że ten brak precyzji Senatu mógłby stanowić kłopot w prawidłowym stosowaniu tego przepisu.

Zaproponowane przez Senat przepisy nie precyzowały ponadto, w jakim trybie kierownik biura powiatowego Agencji Restrukturyzacji i Modernizacji Rolnictwa miałby żądać przedstawienia właściwych dokumentów. Wyjaśnienia wymaga, iż ustawa w brzmieniu sprzed jej nowelizacji nie wskazywała na tryb administracyjnoprawny rozstrzygania spraw o wpis do ewidencji producentów. Wpis był bowiem czynnością materialno-techniczną, a jego dokonanie potwierdzane było wydaniem zaświadczenia, o którym mowa w art. 13 ust. 2 ustawy. Nie jest zatem jasne, jak należałoby traktować proponowany przez Senat RP przepis art. 11 ust. 1a. W świetle okoliczności, iż postępowanie o wpis do ewidencji producentów nie podlega reżi- 
mowi postępowania administracyjnego brak byłoby uregulowania, w jakim trybie takie wezwanie powinno zostać wystosowane, jaka miałaby być reakcja organu w przypadku niedołączenia wymaganych przez kierownika biura powiatowego Agencji dokumentów i w końcu jakie miałoby zostać w takim przypadku wydane rozstrzygnięcie? Nie został ponadto określony termin, w jakim organ może uznać, iż właściwe dokumenty nie zostały dostarczone. Trudno bowiem w takim przypadku byłoby określić, czy brak doręczenia takich dokumentów należałoby traktować jako brak formalny wniosku czy też przesłankę do odmowy wpisu do ewidencji i nadania numeru identyfikacyjnego. Jest to o tyle istotne, że od rozstrzygnięcia wydanego przez kierownika biura powiatowego Agencji w tym zakresie zależy dalszy przebieg postępowania w sprawie, a co za tym idzie sytuacja prawna wnioskodawcy. Akceptacja propozycji Senatu prowadziłaby do sytuacji, w której organ miałby zapewnioną pełną dowolność, oderwaną od konstytucyjnej zasady legalizmu, zgodnie z którą organ działa na podstawie i w granicach prawa.

Warto podkreślić również, iż senacki projekt ustawy nie zawierał przepisów przejściowych regulujących kwestie podmiotów już wpisanych do ewidencji. Biorąc pod uwagę fakt, iż ewidencja powstała na mocy ustawy z 2003 r. należy zakładać, iż znakomita większość wpisów została już dokonana, a ustawa nowelizująca powinna uregulować również sytuację prawną już wpisanych do niej podmiotów.

Sejm RP zgłosił do przedstawionego przez Senat projektu szereg poprawek. Zaproponowano mianowicie oparcie postępowania w sprawie wpisu do ewidencji producentów na przepisach kodeksu postępowania administracyjnego i jednocześnie zaproponowano pewne ograniczenia w stosunku do tych przepisów, mające na celu przerzucenie ciężaru dowodowego na stronę oraz zaktywizowanie strony w toczącym się postępowaniu. Zmieniono ponadto przepis art. 12 ust. 4 dotyczący małżonków, pozostawiając dotychczasową regulację co do zasady oraz określając wyjątek od niej w sytuacji, gdy jedno z małżonków ,prowadzi samodzielnie odrębne gospodarstwo rolne stanowiące zorganizowaną całość gospodarczą".

Przedmiotowe zmiany ocenić należy pozytywnie, zwłaszcza w zakresie ujęcia postępowania o wpis do ewidencji producentów w reżimie kodeksu postępowania administracyjnego. Prowadzenie postępowania administracyjnego daje bowiem organowi możliwość gromadzenia materiału dowodowego, jego oceny i wydanie rozstrzygnięcia zgodnie ze stanem faktycznym i w oparciu o materiał dowodowy potwierdzający dany stan. Powyższe koresponduje w pełni z wyrokiem Trybunału, w szczególności w zakresie przyznania Agencji kompetencji kontrolnych już $\mathrm{w}$ trakcie postępowania o wpis do ewidencji. Także przesunięcie ciężaru dowodowego na stronę postępowania uznać należy za słuszne. Warto w tym miejscu przypomnieć, iż Trybunał wskazał w uzasadnieniu wyroku, iż „to na wnioskodawcach - małżonkach występujących z wnioskiem o osobne wpisy - spoczywa ciężar wy- 
kazania, że posiadają i prowadzą odrębne gospodarstwa rolne”. A zatem wprowadzenie do projektu ustawy przepisów przenoszących ciężar dowodowy na stronę oraz aktywizujące stronę $\mathrm{w}$ postępowaniu, tak aby nie pozostawała bierna i aktywnie uczestniczyła w ustaleniu stanu faktycznego w zakresie posiadania odrębnego od małżonka gospodarstwa rolnego, w szczególności dostarczała dowody na poparcie stawianej tezy prowadzenia niezależnego od małżonka gospodarstwa rolnego, jest słuszne i uzasadnione.

Ponadto podkreślenia wymaga to, że przerzucenie ciężaru dowodowego na osobę, która $\mathrm{z}$ danego faktu wywodzi skutki prawne, nie jest sprzeczne z podstawowymi zasadami procedury administracyjnej. Kodeks postępowania administracyjnego przewiduje bowiem kontradyktoryjny tryb postępowania, np. w przypadku wyznaczenia przez organ rozprawy w sytuacjach spornych. Na rozprawie strony ustosunkowują się do materiału zgromadzonego przez organ, składają wyjaśnienia, zgłaszają żądania, propozycje i zarzuty oraz wypowiadają się co do wyników postępowania administracyjnego. Rozprawa pozwala na wymianę poglądów uczestników postępowania wyjaśniającego, ich uzgadnianie i tworzy możliwość szybkiego komunikowania się, a w rezultacie sprzyja usprawnieniu i uproszczeniu postępowania wyjaśniającego oraz zabezpieczeniu zasady ogólnej szybkości postępowania. Należy podkreślić, że dotychczasowa praktyka, jak też doświadczenia związane z przyznawaniem płatności w ramach systemów wsparcia bezpośredniego, gdzie mają zastosowanie tożsame rozwiązania w zakresie postępowania dowodowego, uzasadniają twierdzenie, że przerzucenie ciężaru dowodowego na osobę, która z danego faktu wywodzi skutki prawne, wpłynie na przyspieszenie prowadzonych postępowań.

Na uwagę zasługuje ponadto użyte przez ustawodawcę sformułowanie definiujące „odrębne gospodarstwo rolne”. Sejm zgłaszając poprawkę do brzmienia art. 12 ust. 4 ustawy użył bowiem określenia: „,w przypadku małżonków oraz podmiotów będących współposiadaczami gospodarstwa rolnego nadaje się odrębny numer identyfikacyjny od numeru, o którym mowa w pkt. 1, jeżeli wnioskodawca prowadzi samodzielnie odrębne gospodarstwo rolne stanowiące zorganizowaną całość gospodarczą". Kwestia ta jest o tyle interesująca, iż ustawa w art. 3 ustawy o KSEP definiuje gospodarstwo rolne jako wszystkie jednostki produkcyjne znajdujące się na terytorium państwa członkowskiego będące w posiadaniu tego samego podmiotu. Nie posługuje się zatem definicją gospodarstwa rolnego sformułowaną w kodeksie cywilnym, przy czym obecnie użyte określenie: „odrębne gospodarstwo rolne stanowiące zorganizowaną całość gospodarczą" wydaje się odsyłać do tej właśnie definicji przy ocenie prowadzenia przez małżonków dwóch gospodarstw rolnych. I choć użyte sformułowanie nie odpowiada wprost definicji gospodarstwa rolnego określonej w art. $55^{3}$ kodeksu cywilnego, i choć ustawodawca nie wskazał wprost, że należy się w takim wypadku posługiwać definicją określoną w przepisach kodeksu cywilnego, to jednak użycie sformułowania „zorganizowana całość gospodar- 
cza" może wskazywać, że ustawodawca dał organowi (Agencji) wskazówkę, w jaki sposób ta odrębność gospodarstw powinna być badana i ustalana. Wykorzystanie do celu oceny odrębności gospodarstw definicji określonej w art. 3 pkt 1 ustawy o KSEP, z uwagi na jej nieprecyzyjność, byłoby trudne i subiektywne. „Zorganizowana całość gospodarcza" jako pojęcie użyte w kodeksie cywilnym, wielorako dyskutowane w doktrynie i w licznych orzeczeniach sądowych, daje organowi pewien wzorzec oceny i czyni ją bardziej obiektywną.

Pozytywnie także należy ocenić wprowadzenie przez Sejm do projektu senackiego przepisów przejściowych do ustawy. W uchwalonej ustawie nowelizującej przyjęto, iż wpisy do ewidencji producentów dokonane przed wejściem w życie ustawy, numery identyfikacyjne nadane przed dniem jej wejścia w życie oraz zaświadczenia o nadanym numerze identyfikacyjnym wydane przed dniem jej wejścia w życie zachowują ważność. Określono ponadto, iż zaświadczenia wydane przed dniem wejście w życie ustawy zmieniającej uznaje się za decyzje administracyjne o wpisie producenta do ewidencji producentów. Taka konstrukcja przepisu zrównuje sytuację prawną podmiotów wpisanych do ewidencji w reżimie ustawy w dotychczasowym brzmieniu i tych, którzy dopiero zamierzają skorzystać z wpisu do ewidencji i dalej z przepisów regulujących przyznanie pomocy finansowej, a uzależniającej tę pomoc od posiadania numeru identyfikacyjnego.

Na ocenę negatywną zasługuje zaś, zmieniony przez Sejm, przepis art. 17, stanowiący delegację dla ministra właściwego do spraw rozwoju wsi do wydania przepisów wykonawczych. O ile bowiem Senat proponował stworzenie katalogu dokumentów, za pomocą których podmiot mógłby udowodnić, iż prowadzone przez niego gospodarstwo stanowi odrębny od gospodarstwa jego małżonka byt, o tyle Sejm w ogóle z tego upoważnienia zrezygnował, ograniczając delegację do określenia wymagań, jakie powinien spełniać wniosek. Wydaje się, iż jest to konsekwencją oparcia postępowania o wpis do ewidencji o reżim postępowania administracyjnego, w tym także dowodowego. I choć można zrozumieć takie stanowisko, to jednak określenie przykładowego zbioru dokumentów czyniłoby postępowanie bardziej transparentnym i ograniczyłoby uznaniowość organu w tej ocenie.

Na krytykę zasługuje również brak w ustawie przepisu obligującego podmiot ubiegający się o wpis do ewidencji w reżimie art. 12 ust. 4 pkt 2 do dołączenia właściwych dokumentów już na etapie złożenia wniosku o wpis do ewidencji producentów. Zgodzić się należy, iż po to postępowanie zostało objęte trybem administracyjnoprawnym, aby organ mógł każdorazowo prowadzić postępowanie dowodowe w wymaganym zakresie, jednakże przepis obligujący do dołączania takich dowodów już na etapie złożenia wniosku znacznie przyspieszyłby procedurę. W takiej sytuacji brak dokumentów dołączonych do wniosku stanowiłby brak formalny wniosku, a pozostawienie sprawy bez rozpoznania nie miałoby negatywnego wpływu 
na sytuację wnioskodawcy. Ponowne złożenie wniosku, z prawidłowo dołączonymi dokumentami, powodowałoby wydanie decyzji o wpisie podmiotu do ewidencji producentów rolnych. Wzywanie zaś każdorazowo do przedłożenia stosownych dokumentów będzie stanowiło przyczynę przedłużania postępowania, a ich niedoręczenie w terminie spowoduje wydanie decyzji negatywnej.

Warto jednocześnie pochylić się nad problemem niedostrzeżonym, jak się wydaje, przez ustawodawcę, dotyczącym małżonków, z których co najmniej jeden nie jest rolnikiem. Należy bowiem podkreślić, iż ewidencja uregulowana przez ustawę o KSEP nie dotyczy wyłącznie rolników, ale także posiadaczy zwierząt, podmiotów prowadzących zakłady utylizacyjne i potencjalnych beneficjentów (art. 3 pkt 2 - definicja producenta). O ile przepis dotyczący wpisywania do ewidencji małżonków będących rolnikami łącznie, a oddzielnie tylko wówczas, gdy prowadzą odrębne gospodarstwa rolne jest jak najbardziej zasadny, o tyle w przypadku posiadaczy zwierząt, potencjalnych beneficjentów oraz podmiotów prowadzących zakłady utylizacyjne jest nadmiernie obciążający i nie znajduje uzasadnienia z punktu widzenia ochrony interesów funduszy Unii Europejskiej. Wypadałoby przytoczyć choćby przypadek schematów pomocowych przyznawanych podmiotom innym niż rolnik. Przykładem może być działanie „Tworzenie i rozwój mikroprzedsiębiorstw”, gdzie płatności przyznaje się na rzecz osoby fizycznej, prawnej, spółki cywilnej oraz spółek osobowych prowadzących działalność gospodarczą, a nie rolniczą, więc ograniczanie możliwości wpisu do ewidencji małżonka osoby prowadzącej działalność gospodarczą jest zbędne z punktu widzenia celu, dla którego przepis art. 12 ust. 4 został ustanowiony. Niestety, w ustawie sprzed nowelizacji brak było wyjątków od zasady łącznego wpisywania do ewidencji małżonków, co tym samym wykluczyło możliwość nadania odrębnego numeru małżonkowi, który prowadzi działalność gospodarczą niezwiązaną z prowadzeniem wspólnego gospodarstwa rolnego. W ustawie nowelizującej kwestia ta nie została podjęta.

\section{Podsumowanie}

Ostatecznie ustawa nowelizująca ustawę o KSEP została uchwalona po odrzuceniu wniosku Senatu o odrzucenie poprawek zgłoszonych przez Sejm. Zatem wszystkie poprawki Sejmu zostały uwzględnione. Można ocenić, iż zasadnicze wymagania postawione ustawodawcy przez Trybunał Konstytucyjny zostały uwzględnione. W szczególności osiągnięty został postulowany przez Trybunał efekt umożliwienia małżonkom oddzielnego wpisu do ewidencji producentów rolnych, pod warunkiem posiadania i prowadzenia oddzielnych gospodarstw rolnych. Jednocześnie umożliwiono Agencji Restrukturyzacji i Modernizacji Rolnictwa prowadzenie postępowania administracyjnego, w tym dowodowego, w zakresie stwierdzenia samodzielności i odrębności gospodarstw rolnych małżonków, co może stanowić skuteczne 
narzędzie w wykrywaniu tworzenia przez wnioskodawców sztucznych warunków dla uzyskania wyższych płatności, chroniąc interesy finansowe Unii Europejskiej. ${ }^{15}$ Polityki Rolnej, „Studia luridica Agraria” 2012, t. X, s. 422-440. 
NATIONAL SYSTEM OF RECORDS OF AGRICULTURAL PRODUCERS FOLLOWING THE DECISION OF THE CONSTITUTIONAL COURT

OF 3 DECEMBER, 2013 (REF. NO. P 40/12)

Keywords: The Constitutional Court, the national system of records of agricultural producers, spouses

On January 1, 2015 the Law of 23 October, 2014 comes into force amending the Act on the national system of records of producers, of homesteads and of applications for payments. The amendment to the Act is the corollary of the decision of the Constitutional Court of 3 December 2013, (Ref. No. P 40/12), in which, after examining the issue of the legal question presented in the High Administrative Court, on the regulation of Art. 12 paragraph. 4 of the Act, the Court held that this provision to the extent that does not provide for the admissibility of individual identification numbers given to each of the spouses in a situation where there is division of marital property and they own separate farms, is at variance with Art. 32 paragraph. 1 in conjunction with Art. 18 of the Constitution.

This article is an attempt to evaluate the effectiveness of the implementation by the legislator of the guidelines made by the Constitutional Court in support of the decision in the light of the threat, under the new legal framework, of creating by the spouses artificial conditions for obtaining public assistance. 